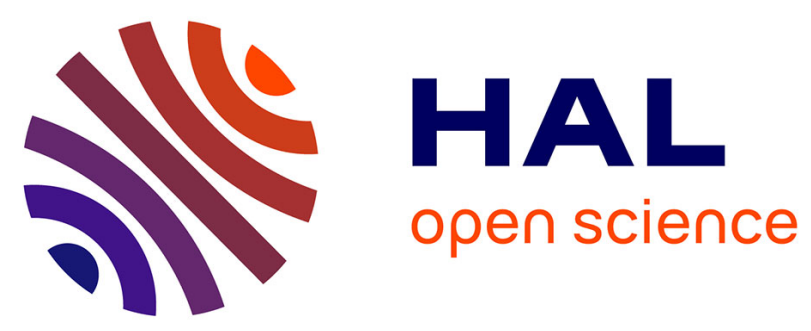

\title{
Properties of hydric and biodegradability of cassava starch-based bioplastics reinforced with thermally modified kaolin
}

Namory Méité, Léon Koffi Konan, Monique Tohoué Tognonvi, Bi Irié Hervé

Goure Doubi, Moussa Gomina, Samuel Oyetola

\section{To cite this version:}

Namory Méité, Léon Koffi Konan, Monique Tohoué Tognonvi, Bi Irié Hervé Goure Doubi, Moussa Gomina, et al.. Properties of hydric and biodegradability of cassava starch-based bioplastics reinforced with thermally modified kaolin. Carbohydrate Polymers, 2021, 254, pp.117322. 10.1016/j.carbpol.2020.117322 . hal-03456302

\section{HAL Id: hal-03456302 https://hal.science/hal-03456302}

Submitted on 30 Nov 2021

HAL is a multi-disciplinary open access archive for the deposit and dissemination of scientific research documents, whether they are published or not. The documents may come from teaching and research institutions in France or abroad, or from public or private research centers.
L'archive ouverte pluridisciplinaire HAL, est destinée au dépôt et à la diffusion de documents scientifiques de niveau recherche, publiés ou non, émanant des établissements d'enseignement et de recherche français ou étrangers, des laboratoires publics ou privés. 


\section{Journal Pre-proof}

Properties of hydric and biodegradability of cassava starch-based bioplastics reinforced with thermally modified kaolin

Namory Méité, Léon Koffi Konan, Monique Tohoué Tognonvi, Bi Irié Hervé Goure Doubi, Moussa Gomina, Samuel Oyetola

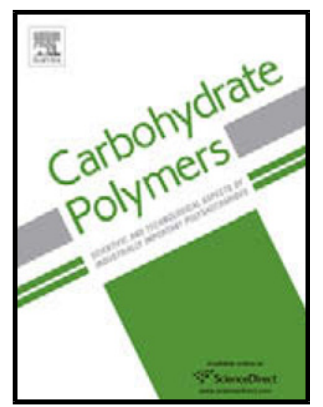

PII: $\quad$ S0144-8617(20)31495-8

DOI: $\quad$ https://doi.org/10.1016/j.carbpol.2020.117322

Reference: CARP 117322

To appear in: $\quad$ Carbohydrate Polymers

Received Date: $\quad 10$ June 2020

Revised Date: $\quad 23$ October 2020

Accepted Date: $\quad 23$ October 2020

Please cite this article as: Méité N, Konan LK, Tognonvi MT, Doubi BIHG, Gomina M, Oyetola $\mathrm{S}$, Properties of hydric and biodegradability of cassava starch-based bioplastics reinforced with thermally modified kaolin, Carbohydrate Polymers (2020), doi: https://doi.org/10.1016/j.carbpol.2020.117322

This is a PDF file of an article that has undergone enhancements after acceptance, such as the addition of a cover page and metadata, and formatting for readability, but it is not yet the definitive version of record. This version will undergo additional copyediting, typesetting and review before it is published in its final form, but we are providing this version to give early visibility of the article. Please note that, during the production process, errors may be discovered which could affect the content, and all legal disclaimers that apply to the journal pertain.

(c) 2020 Published by Elsevier. 


\title{
Properties of hydric and biodegradability of cassava starch-based bioplastics reinforced
} with thermally modified kaolin

\section{Namory Méité1a*; Léon Koffi Konan ${ }^{1 \mathrm{~b}}$; Monique Tohoué Tognonvi² ${ }^{2 c}$ Bi Irié Hervé Goure}

Doubi $^{2 \mathrm{~d}}$; Moussa Gomina ${ }^{3 \mathrm{e}}$; Samuel Oyetola ${ }^{1 \mathrm{f}}$

${ }^{1}$ Laboratoire de Chimie des Matériaux Inorganiques (LCMI), UFR SSMT, Université Félix

Houphouët-Boigny-Cocody, 22 BP 582 Abidjan 22, Côte d'Ivoire.

${ }^{2}$ Unité de formation de recherche sciences biologiques, Université Peleforo Gon Coulibaly de Korhogo, BP 1328 Korhogo, Côte d'Ivoire.

${ }^{3}$ Laboratoire CRISMAT UMR 6508 ENSICAEN, CNRS ENSICAEN, 6 Bd Maréchal Juin, 14050, Caen

\section{Cedex 4, France}

anamorymeite2986@gmail.com, ${ }^{b}$ leonkonan2000@yahoo.fr, ${ }^{c}$ monique.tognonvi@upgc.edu.ci, ${ }^{d}$ goure_herve2610@yahoo.fr, ${ }^{e}$ moussa.gomina@ensicaen.f $r,{ }^{f}$ oyetolasamuel@yahoo.fr

*Corresponding author: Namory Méité

E-mail address: namorymeite2986@gmail.com

Highlights

- Kaolin-reinforced starch-based bioplastics were manufactured

- Incorporating kaolin-based clay enhanced the solubility of bioplastics

- Thermally treatment of kaolin better improved the hydric properties of bioplastics

- Metakaolin platelets significantly refined the bioplastic microstructure

\begin{abstract}
:
In this study, hydric and biodegradability properties of cassava starch-based bioplastics reinforced with crude kaolin or treated kaolinitic clay at $700{ }^{\circ} \mathrm{C}$ called metakaolin were investigated using water adsorption and microbiological tests. Non-reinforced bioplastics (BP) and those containing 5 wt.\%
\end{abstract}


crude kaolin (BPKB) or metakaolin (BPMKB) were manufactured using the casting/evaporation method. Results obtained showed a decrease in the solubility and in the water diffusion and permeability of clay-reinforced bioplastics with respect to the ones without reinforcement. This improvement of the hydric properties has been attributed to the reduction in the free volumes existing between the starch macromolecules due to their interactions with clay platelets. These interactions might favor a more homogeneous and compact microstructure. The biodegradability of the clay reinforced bioplastics was significantly improved due to the bacterial proliferation. The thermal treatment of kaolinitic clay further improved the hydric and biodegradability properties of starch-based bioplastics.

Keywords: Cassava starch-based bioplastic; Kaolin; Metakaolin; Hydric properties; Biodegradability

\section{Introduction}

The ever-growing utilization of plastic materials from petrochemical sources is necessarily accompanied by environmental repercussions. The vast majority of these plastic wastes are non-biodegradable. They can remain in the environment for very long periods (100 to 1000 years). In addition, the incineration of such wastes is very polluting. It releases significant amounts of carbon dioxide and other toxic gases harmful to the environment and human health (Belyamani, 2012).

Addressing plastic pollution, therefore, requires the development of biodegradable biopolymers, as an alternative to synthetic polymers. Thermoplastic packaging has considerably expanded in recent years. They possess the advantage of being inexpensive (raw materials), lighter, impact resistant and easy to implement. In addition, they are biodegradable, which prevents them from piling up in landfills. Biodegradation is a catalyzed degradation (in the soil or on the soil surface) by micro-organisms (Siracusa, 2019). Then, the material structure is simplified to finally convert into $\mathrm{H}_{2} \mathrm{O}, \mathrm{CO}_{2}, \mathrm{CH}_{4}$, and/or into a new biomass and eventually to a non-toxic residue for humans and the environment. 
Starch is a natural polymer that can be easily plasticized by means of glycerol (Tyagi \& Bhattacharya, 2019). However, starch-based bioplastics are generally characterized by weak mechanical properties and a high water sensitivity (Kaewtatip \& Tanrattanakul, 2012 ; Souza et al., 2012). Their functional properties can be improved by using reinforcements such as vegetable fibers, celluloses and clays. The growing interest in clays is justified by their abundance in nature, their nanometric size, and their biocompatibility. The montmorillonite type lamellar structure clays are increasingly used as reinforcements in polymer matrices because of their ability to easily exfoliate (Islam et al., 2020). By dispersing them at the nanometric level, these minerals considerably increase the mechanical properties and the impermeability level with a low charge rate.

On the other hand, kaolinitic clays, although abundantly available in Côte d'Ivoire, remain hardly used (Sei et al., 2002; Konan et al., 2006). In fact, the interlayer hydrogen bonding and the low permanent charge of the sheets give them a non-expandable character which makes their dispersion in the polymer matrix difficult. Obtaining less cohesive kaolinite has often been achieved through a chemical treatment with dimethyl sulfoxide (DMSO). Meite et al. (2018) have showed that the thermal treatment of the kaolin (labelled KF) at $700{ }^{\circ} \mathrm{C}$ for 1 hour improves the physico-chemical properties of the bioplastics. The utilization of heattreated kaolin as reinforcement in bioplastics is likely to avoid environmental toxicity issues contrary to chemical additives. In this study, hydric and biodegradability properties of cassava starch-based bioplastics reinforced with crude kaolin or heat treated kaolinitic clay at $700{ }^{\circ} \mathrm{C}$ called metakaolin with respect to the interaction between cassava starch and kaolin, in two different crystalline forms were studied. After discussing the notable structural differences between kaolin and metakaolin, evidenced by different techniques, the water adsorption and the mass loss of the samples as a function of the exposure time on the soil surface and the burial time in the ground were evaluated. 


\section{Materials and methods}

\subsection{Materials}

The starch used is obtained from a variety of cassava called Bocou 2 (Manihot Esculenta crantz). The tubers were harvested in the region of Yamoussoukro, on the site of $06^{\circ} 53^{\prime} 785^{\prime \prime}$ $\mathrm{N}$ and $05^{\circ} 14^{\prime} 441^{\prime} \mathrm{W}$ geographic coordinates. Glycerol (50\% volume) provided by a local company was used as a plasticizer to manufacture the starch-based bioplastics. A $0.1 \mathrm{~mol} / \mathrm{L}$ hydrochloric acid solution prepared from a commercial solution ( $\mathrm{HCl}$, Sigma-Aldrich) was used to promote starch chains destructuring. A sodium hydroxide of $0.1 \mathrm{~mol} / \mathrm{L}(\mathrm{NaOH}$, Sigma-Aldrich) was also used for the $\mathrm{pH}$ stabilization. The kaolin clay (labelled KB) was collected from Yaou, a village located in South-Est of Côte d'Ivoire. The geographic coordinates of the sampling site are $05^{\circ} 15^{\prime} 013^{\prime \prime} \mathrm{N}$ and $03^{\circ} 37^{\prime} 485^{\prime \prime} \mathrm{W}$. The metakaolin (denoted MKB) was obtained after calcining the crude kaolin at $700{ }^{\circ} \mathrm{C}$ for $1 \mathrm{~h}$ by means of a programmable Nabertherm type furnace with a heating rate of $5^{\circ} \mathrm{C} / \mathrm{min}$.

\subsection{Bioplastic preparation}

Non-reinforced bioplastics (BP) and bioplastics containing $5 \mathrm{wt} \%$ of crude kaolin (BPKB) or metakaolin (BPMKB) were prepared according to the procedure described in previous work through the casting/evaporation method (Meite et al., 2018). A mixture of $2.5 \mathrm{~g}$ of the starch, $4 \mathrm{~mL}$ of glycerol (50\% Vol.), and $3 \mathrm{~mL}$ of $\mathrm{HCl}(0.1 \mathrm{~mol} / \mathrm{L})$ was poured into $25 \mathrm{~mL}$ of distilled water under magnetic stirring (250 tr/min) for $30 \mathrm{~min}$. Thereafter, $5 \mathrm{wt} \% \mathrm{~KB}$ or MKB was added followed by $30 \mathrm{~min}$ of magnetic stirring at room temperature (range of $20-25^{\circ} \mathrm{C}$ ). The obtained homogeneous mixture was then heated by means of an electronic hot plate up to 100 $\pm 1^{\circ} \mathrm{C}$ under constant stirring. After $10 \mathrm{~min}$ of stirring, $2 \mathrm{~mL}$ of $\mathrm{NaOH}(0.1 \mathrm{~mol} / \mathrm{L})$ was added in order to decrease the mixture viscosity and acidity, still under thermal agitation for another 5 min. Finally, this hot gel-like suspension was cast in Petri dishes and allowed to dry at room temperature for $72 \mathrm{~h}$ before demoulding. The tests were repeated three times in each case. 


\subsection{Methods}

\subsubsection{Chemical compositions}

The chemical analysis of the clay used in this study was determined by means of Inductively Coupled Plasma Atomic Emission Spectrometry (ICP-AES) method using a Thermo Jarrell Ash Corporation IRIS spectrometer. Before analysis, clay sample was dried $\left(110{ }^{\circ} \mathrm{C}\right.$ for $\left.24 \mathrm{~h}\right)$ and then about $20 \mathrm{mg}$ were dissolved in an acidic solution (fluorhydric and nitric acids) by means of a microwave digestion technique. The obtained diluted solutions were then submitted to ICP-AES analysis. The latter was based on exciting the metal atoms/ions using a plasma and analyzing the emission wavelength of the electromagnetic radiation, which was typical of that particular metal (Arvis \& Jarvis, 1992).

\subsubsection{Specific surface area measurement}

The specific surface area of kaolin and metakaolin was performed on a Micromeritics Tristar II type device using the BET method (Brunauer, Emmett and Teller). Before the measurements, the samples were degassed under vacuum at $200{ }^{\circ} \mathrm{C}$ for $16 \mathrm{~h}$.

\subsubsection{Amylose and amylopectin contents}

For the starch, the amylose and amylopectin contents were determined in accordance with the method developed by Freitas et al. (2004). This method was based on a calibration curve obtained from a mixture in water of pure amylose and amylopectine in mass proportions ranging from 0 to $100 \%$. A lipid free starch was prepared according to Soxhlet method for $6 \mathrm{~h}$ and dried at $80^{\circ} \mathrm{C}$ for $3 \mathrm{~h} .0 .5 \mathrm{~g}$ of the obtained product was dissolved in $100 \mathrm{~mL}$ of distilled water. Adding $0.1 \mathrm{~mL}$ of Lugol $\left(\mathrm{I}_{2} / \mathrm{KI}\right)$ (Sigma-Aldrich) to $5 \mathrm{~mL}$ of the 5 times diluted solution enabled to measure the absorbance or optical density (OD) and therefore to determine the amylose content using the calibration curve. The amylopectin content was then deducted from the relation (1): 
Amylopectin content $(w t \%)=100-$ Amylose content $(w t \%)$

\subsubsection{Ash content}

Ash content of the starch (Ta) was evaluated through a calcination process at $550{ }^{\circ} \mathrm{C}$ using Nabertherm-type furnace for $3 \mathrm{~h}$. Ta has been calculated according to the relation (2):

$T a=\frac{M a}{M i} \times 100$

With Ma, mass of starch ash and Mi, the initial mass.

\subsection{5 pH measurements}

$\mathrm{pH}$ measurements were carried out on the starch supernatant by means of inoLab pH/ION/Cond 750 type $\mathrm{pH}-$ Meter. The supernatant was obtained after centrifugation at 3000 $\mathrm{rpm}$ for $10 \mathrm{~min}$ from the slurries prepared with $2.5 \mathrm{~g}$ of starch and $5 \%$ of $\mathrm{KB}$ or MKB in 25 $\mathrm{mL}$ of distilled water.

\subsubsection{X-ray diffraction}

The X-ray diffraction experiments were performed using a Siemens d5000 diffractometer. This apparatus was equipped with a copper anticathode $(\lambda=1.54 \AA)$. The analyses were carried out on powdered material (KB and MKB) with particle size below $100 \mu \mathrm{m}$. Patterns were collected over the $2 \theta$ range of $5-60^{\circ}$ with a step size of $0.02^{\circ}$ and a counting time of 10.1 seconds per step.

\subsubsection{Scanning electron microscopy}

The microstructure observation of the samples was carried out using a MEB FEG Supra 40 VP Zeiss scanning electron microscope (SEM). For calibration, we chose a diameter of 30 $\mathrm{mm}$ and a probe's energy of $20.1 \mathrm{KeV}$. The working distance was set at $\mathrm{WD}=8.4 \mathrm{~mm}$. The bioplastic samples were mounted on platinum stubs for viewing. The acquisition of SEM images was performed in at least three different areas.

\subsubsection{Hydric property measurements}


The water solubility of the bioplastics produced was assessed by measuring the weight loss during an immersion time of $24 \mathrm{~h}$ in pure water.

Adsorption isotherms were obtained by maintaining the plastic films of $15 \times 30 \times 1.4 \mathrm{~mm}^{3}$ in dimensions in a controlled chamber at a constant temperature of $25^{\circ} \mathrm{C}$ and a given relative humidity (RH varying from 0 to $97.8 \%$ ) (Greenspan, 1977). Samples were weighed using a precision balance at regular interval time of $4 \mathrm{~h}$ until a constant mass. These measurements enabled to obtain the wet mass $(\mathrm{Me})$ of the product. The dry weight (Ms) was determined after drying at $105{ }^{\circ} \mathrm{C}$ for $48 \mathrm{~h}$. Knowing those two weights (Me and Ms) allowed to infer the bioplastic water (or moisture) content (Xi) at the equilibrium according to the relation (3):

$$
X_{i}=\frac{M_{e}-M_{S}}{M_{S}}
$$

Isotherms were obtained by plotting the water content $(\mathrm{Xi})$ as a function of the water activity ( $\mathrm{a}_{\mathrm{w}}$ varying from 0 to 1 ).

The coefficients of the diffusion and permeability of water were measured by the gravimetric method on the previously dried samples $\left(105^{\circ} \mathrm{C}\right.$ for $\left.48 \mathrm{~h}\right)$. The point cloud was obtained by drawing the mass of the absorbed water as a function of time according to the relation (4):

$$
\frac{M_{t}-M_{0}}{M_{\infty}}=\frac{4}{e} \sqrt{\frac{D}{\pi}} t^{1 / 2}
$$

where $\mathrm{M}_{0}(\mathrm{~g})$ was the initial mass, $\mathrm{M}_{\mathrm{t}}$, the mass at a given time $\mathrm{t}, M_{\infty}$ the mass at the equilibrium, $t$, the time in second and $\mathrm{D}$, the diffusion coefficient $\left(\mathrm{m}^{2} \cdot \mathrm{s}^{-1}\right)$.

The slope of the correlation line enabled to determine the diffusion coefficient (D) in accordance with the relations (5):

$$
D=\pi \times\left(\frac{\alpha e}{4}\right)^{2}
$$

with $\boldsymbol{\alpha}$ the slope of the correlation line $\left(\mathrm{kg} . \mathrm{s}^{-1}\right)$ and e the thickness of the bioplastics film (m) (Greenspan, 1977).

The coefficient of water permeability (P) was assessed following the relation (6): 


$$
P=\frac{\alpha e}{A \times M\left(p_{1}-p_{2}\right)}
$$

where $\mathrm{A}$ is the area of the exposed film $\left(\mathrm{m}^{2}\right), \mathrm{M}$, the molecular mass of water $\left(\mathrm{kg} \cdot \mathrm{mol}^{-1}\right)$, and $\mathrm{p}_{1}-\mathrm{p}_{2}$ the difference of the vapor pressure on the film (Pa) (Chivrac et al., 2010).

\subsubsection{Biodegradability}

The biodegradability was assessed by in situ tests. The bioplastics film of $\left(15\right.$ x 30 x $\left.1.4 \mathrm{~mm}^{3}\right)$ in dimension were either completely buried $3 \mathrm{~cm}$ deep in the ground or deposited on the surface of $100 \mathrm{~g}$ of soil, placed in containers (climatic chamber at $\mathrm{T}=25^{\circ} \mathrm{C}, \mathrm{P}=1 \mathrm{bar}$ ). Then, they were watered each three days to ensure a fairly high humidity. After a determined exposure time, the mass changes were recorded for each sample. To identify microorganisms, a medium composed of $1 \mathrm{~g}$ of meat peptone (emulsifier), $5 \mathrm{~g}$ of $\mathrm{NaCl}, 2 \mathrm{~g}$ of $\mathrm{KH}_{2} \mathrm{PO}_{4}, 20 \mathrm{~g}$ of plastic film and $20 \mathrm{~g}$ of agar agar (E406 gelling agent) was prepared. The whole was placed in $1000 \mathrm{~mL}$ of distilled water and sterilized at $121^{\circ} \mathrm{C}$ for $15 \mathrm{~min}$. Then, the inoculum was prepared by homogenizing $10 \mathrm{~g}$ of soil in $90 \mathrm{~mL}$ of physiological water $(\mathrm{NaCl}$ 9/1000 $\mathrm{mL}$ of distilled water). The petri dishes were poured by flooding ( $1 \mathrm{~mL}$ of inoculum). These tests were repeated three times for each formulation.

\section{Results and discussion}

\subsection{Physico-chemical characterization of the cassava starch and the kaolin}

The amylose and amylopectin contents were 21.2 and $78.8 \%$, respectively. These values were consistent with those generally observed for cassava starches (Sidibé et al., 2010). The water content was $\mathrm{Te}=10.22 \pm 0.01 \%$. This value was lower than the one obtained by Belibi (2013) for the cassava starch shrub (12.9\%) and by Yéboué et al. (2017) for cassava starch IAC (15.15\%). This difference could be explained by several internal factors, namely: the starch physicochemical composition, the botanical origin, the variety of cassava but also by the humidity of the storage atmosphere $\left(\mathrm{T}=25^{\circ} \mathrm{C} ; \mathrm{RH}=50 \%\right)$. The $\mathrm{pH}$ of the supernatant from cassava starch slurries was 4.7 . This acid character which could be attributed to the nature of 
the soil and/or to the method of starch extraction has also been reported by other authors (Mbey, 2013 ; Yéboué et al., 2017).

Chemical and mineralogical composition of kaolin $(\mathrm{KB})$ along with its physical parameters are documented in Table 1. The chemical analysis showed that KB was mainly composed of silica and alumina. Iron, titanium, potassium and sodium were also present but in very small quantities.

Table 1: Physico-chemical and mineralogical parameters of the studied kaolin (KB)

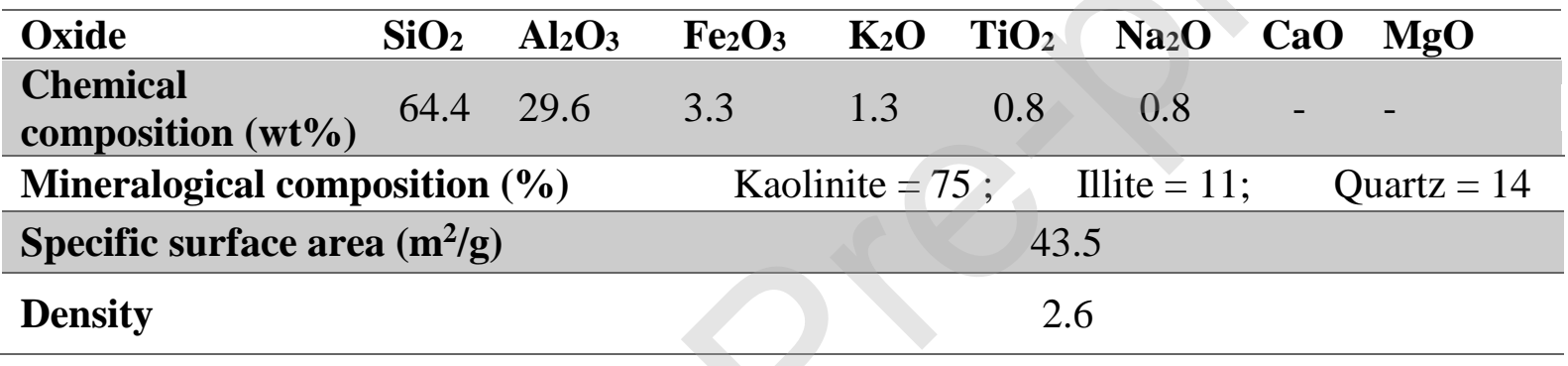

Combining the chemical composition results with the ideal chemical formula of the mineralogical phases detected by X-ray diffraction (Figure 1), and using the law of mixtures, allowed to determine the kaolin mineralogical proportions as follows: $75 \%$ of kaolinite, $11 \%$ of illite and $14 \%$ of quartz. The specific surface area estimated at $43.5 \mathrm{~m}^{2} / \mathrm{g}$ was relatively high for a kaolinitic clay. This could result from the presence of iron oxide highlighted by the chemical analysis. However, peaks corresponding to the ferric phases were not detected by XRD analysis (Figure 1), probably because of their low content. The density value obtained corresponded to that generally observed for a kaolinitic type clay (Amon et al., 2017).

\subsection{Effect of the thermal treatment on the kaolin}


Figure 1 shows the x-ray diffraction patterns of both the crude kaolin and the metakaolin. $\mathrm{XRD}$ diffractogram of $\mathrm{KB}$ revealed the presence of peaks attributed to kaolinite $\left(2 \theta=12^{\circ}\right.$; $\left.25^{\circ} ; 35^{\circ}\right)$, illite $\left(2 \theta=9^{\circ} ; 19,70^{\circ} ; 29,36^{\circ}\right)$ and quartz $\left(2 \theta=26^{\circ} ; 36^{\circ} ; 50^{\circ}\right)$.

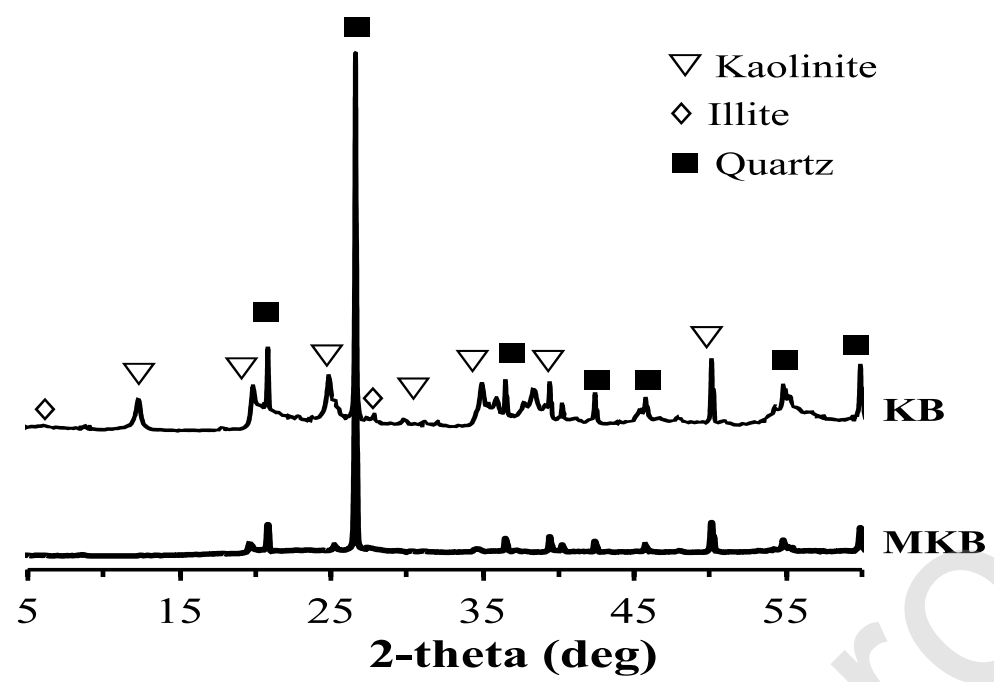

Figure 1: X-ray diffraction patterns of kaolin $(\mathrm{KB})$ and metakaolin $(\mathrm{MKB})$.

The diffractogram of MKB presented only the peaks of quartz. The disappearance of the characteristic peaks of kaolinite and illite was linked to the transformation of kaolin into metakaolin during the heat treatment. The metakaolin, product of the heat treatment above $500{ }^{\circ} \mathrm{C}$ of the kaolin, was characterized by an absence of a long-range order in the arrangement of the atoms of the main clay phases (Konan et al., 2010 ; Meite et al., 2018). Kaolinite transformation into metakaolinite can be described by the following reaction (7): kaolinite $\left(\mathrm{Al}_{2} \mathrm{O}_{3} \cdot 2 \mathrm{SiO}_{2} \cdot 2 \mathrm{H}_{2} \mathrm{O}\right) \stackrel{400-700^{\circ} \mathrm{C}}{\longrightarrow}$ metakaolinite $\left(\mathrm{Al}_{2} \mathrm{O}_{3} \cdot 2 \mathrm{SiO}_{2}\right)+2 \mathrm{H}_{2} \mathrm{O}(7)$. The departure of hydroxyl groups in the form of water contained in the mineral led to significant structural modifications within the metakaolinite. The structural change is characterized by a loss of crystallinity, weight loss and a concomitant change in aluminium coordination from octahedral to tetrahedral (Sperinck et al., 2011).

\subsection{Visual aspect of the bioplastics}

The bioplastics BP, BPKB and BPMKB obtained are shown in Figure 2. The visual observation of the bioplastics appearance revealed a better dispersion of metakaolin in the 
matrix, resulting in a more homogeneous and more transparent material than bioplastic incorporating crude kaolin. In general, adding mineral clays into the bioplastic resulted in a loss of transparency due to the red color provided by the Kaolin. The transparency of BPMKB against BPKB could be explained by the decomposition of the coloring oxides present in kaolin such as iron oxyhydroxides under the heat influence. Often, this reduction in the transparency is beneficial for the preservation of certain products because the light accelerates their oxidation.
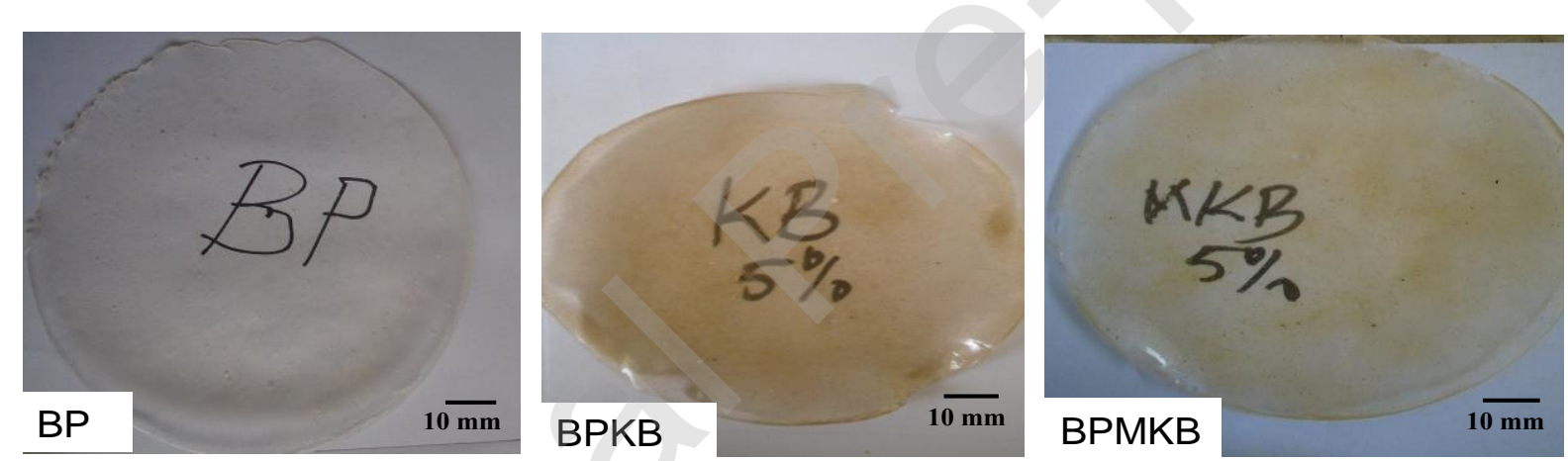

Figure 2: Photographs of the produced bioplastics. BP, Non-reinforced bioplastics; BPKB, Reinforced bioplastics with crude kaolin; BPMKB, Reinforced bioplastics with metakaolin

\subsection{Hydric properties of bioplastics}

\subsubsection{Solubility}

The solubility value for BP was $35.6 \%$. This value decreased to $29.6 \%$ and $22.1 \%$ for BPKB and BPMKB respectively. The reduction in the solubility on addition of clay minerals suggests an improvement of the water resistance of the materials. This increase in the water resistance of bioplastics when they are reinforced with kaolin could be explained by the 
fineness of the clay particles and the interactions between the macromolecules of starch and the clay (Wahyuningtiyas \& Suryanto, 2018 ). The drop in the solubility could also be explained by the hydrophobic character of both kaolin and metakaolin. Owing to their nanometric sizes, clay particles could fill the bioplastics pores, increasing their compactness and improving their resistance to water. This water resistance of bioplastics was more pronounced when metakaolin was used as a reinforcement.

\subsubsection{Water adsorption}

Figure 3 shows the change in the water content at equilibrium as a function of water activity for the bioplastics BP, BPKB and BPMKB.

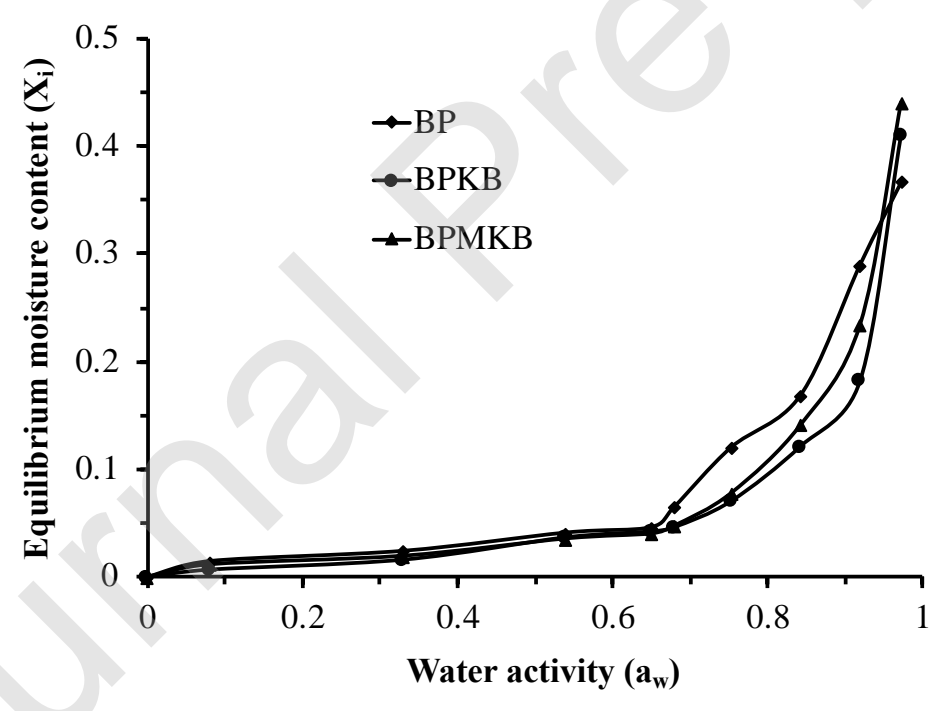

Figure 3: Adsorption isotherms of bioplastics. BP, Non-reinforced bioplastics; BPKB, Reinforced bioplastics with crude kaolin; BPMKB, Reinforced bioplastics with metakaolin The obtained isotherms had a similar appearance to those generally observed for hydrophilic materials. They showed two phases: a first phase (from 0 to 0.7 ) where the adsorption was low and a second one where the adsorption increased rapidly ( $a_{w}$ higher than 0.7$)$. For the 
moisture content lower than 0.7 , all bioplastics had almost identical behavior. For activities $\left(a_{w}\right)$ ranged from 0.7 to 0.9 , the adsorbed water content decreased when the bioplastic was reinforced with clay. This decrease was more marked when the reinforcement was metakaolin. This could be explained by the compact arrangement of the macromolecular chains in BPMKB since the free volume (pores) existing between the macromolecules were reduced due to the interactions between the starch molecules and the metakaolin platelets. These results were in line with the ones observed with extruded wheat starch-based bioplastics reinforced with nanoclay (Wahyuningtiyas \& Suryanto, 2018 ).

\subsubsection{Diffusion and permeability coefficients of bioplastics}

Figure 4 depicts the variation of the weight of absorbed water as a function of time for the studied bioplastics BP, BPKB and BPMKB. An increase in the mass over time was observed for all the manufactured bioplastics.

The distribution of the values could be represented by a straight line whose linear regression coefficient $\mathrm{R}^{2}$ close to 1 , enabled the calculation of the permeability and diffusion coefficients with good reliability from the slope of the straight line. The calculated values are shown in

Table 2.
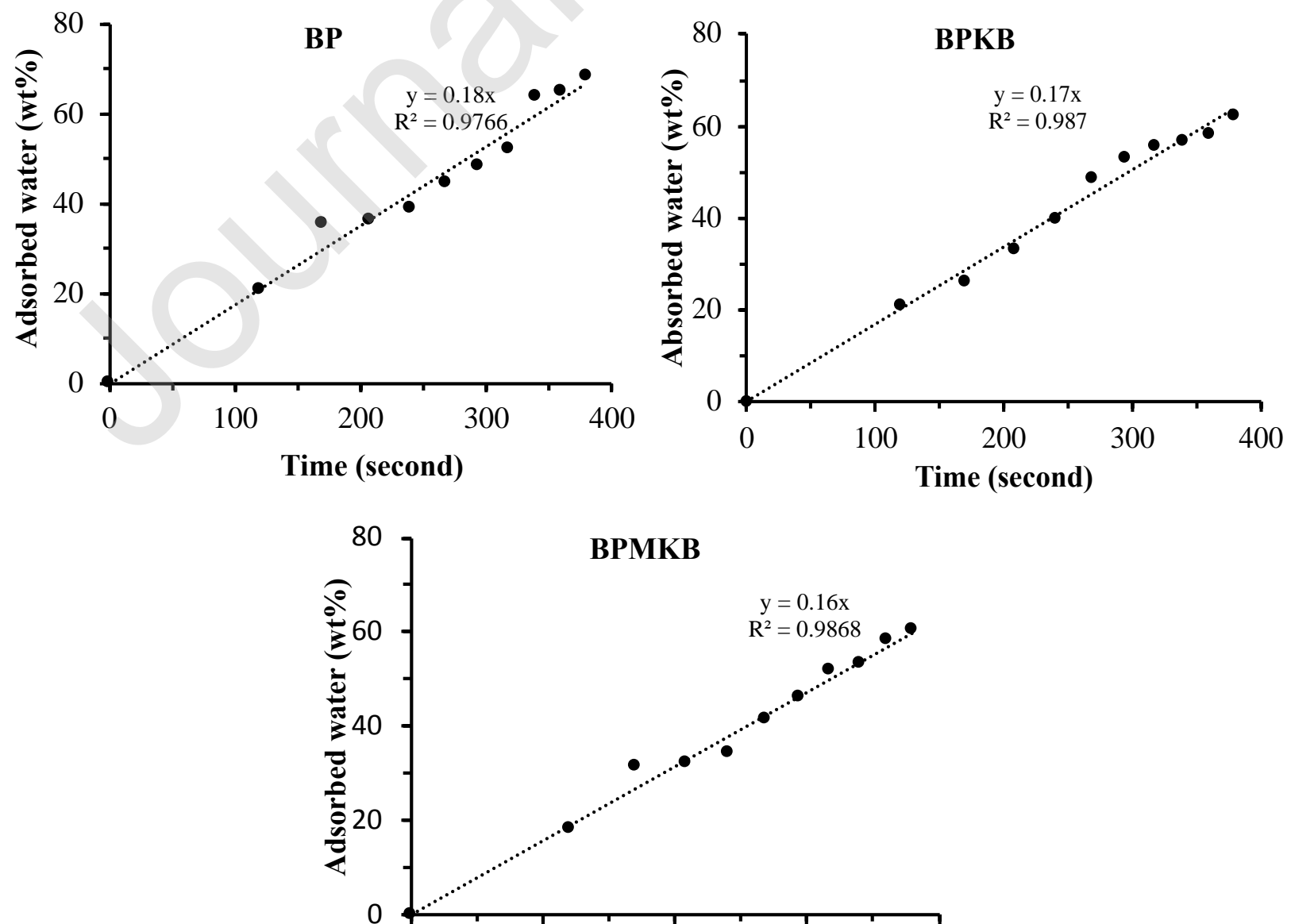
Figure 4: Change in the mass of the absorbed water as a function of time.

Table 2: Coefficients of diffusion and permeability of bioplastics. BP, Non-reinforced bioplastics; BPKB, Reinforced bioplastics with crude kaolin; BPMKB, Reinforced bioplastics with metakaolin

\begin{tabular}{lll}
\hline Bioplastics & $\begin{array}{l}\text { Permeability } \\
(\mathbf{1 0}\end{array}$ & $\begin{array}{l}\text { Diffusion } \\
\left(\mathbf{1 0}^{-\mathbf{1 2}} \mathbf{m}^{\mathbf{2}} \mathbf{~ s}^{-\mathbf{1}} \mathbf{)}\right.\end{array}$ \\
\hline BP & $\left.\mathbf{s}^{\mathbf{- 1}} \mathbf{P a}^{-\mathbf{1}}\right)$ & $3.58 \pm 0.04$ \\
\hline BPKB & $3.78 \pm 0.03$ & $3.18 \pm 0.01$ \\
\hline BPMKB & $3.58 \pm 0.05$ & $2.83 \pm 0.02$ \\
\hline
\end{tabular}

Water permeability and diffusion dropped when bioplastics were reinforced with kaolin and metakaolin. The decrease was more pronounced when the mineral load was metakaolin. This decrease in water permeability and diffusion could be explained by the reduction in the free volumes (pores) existing between the starch macromolecules. Incorporating the thermally treated clay further decreased the water sensibility and diffusion of bioplastics. The molecular interactions between metakaolin platelets and functional groups of starch macromolecules would lead to the production of a more compact material. These results were in accordance with those obtained by Chivrac et al. (2010), who observed a reduction in the diffusion coefficient of bioplastics based on cassava starch reinforced with montmorillonite. Also, these variations were in line with those obtained for the solubility of bioplastics when heat treated kaolin was used as reinforcement instead of crude kaolin.

\subsection{Microstructure of bioplastics}


Figure 5 depicts the microstructure of the studied bioplastics. SEM images of BP showed a smooth and homogeneous microstructure resulting in a regular surface. The high water solubility of this material suggested that the macromolecules of the starch were linked through weak bonds including hydrogen bonds. During the gelatinization process, the water trapped inside the starch was slowly evaporated giving rise to a smooth and homogeneous gel surface (Figure 5-BP). SEM images of BPKB revealed defects, pores, cracks, etc. resulting in a more porous and irregular surface. This may be due to a weak cohesion between the starch and the kaolin. In the case of BPMKB, despite the presence of some surface defects, the microstructure appeared denser suggesting a better interaction between the starch and the metakaolin. It has been shown that incorporating clay in the bioplastic decreases the material solubility. During the film formation process, starch may react with the clay allowing clay fine particle dispersion within the gelatinized starch. Since, the process was performed around $100{ }^{\circ} \mathrm{C}$, the water that was present on the film layer had evaporated (Cruz-Tirado et al., 2020). However, the water vapor that was trapped inside the clay platelet would cause deformation and cracks in the case of BPKB related to the poor dispersion of the kaolin. In the case of BPMKB, due to the thermal treatment, there was no water in the structure. This may allow a stronger interaction between the metakaolin and the starch. The evaporation of the water present on the film surface would cause deformation, but no cracks, as shown in the SEM images.
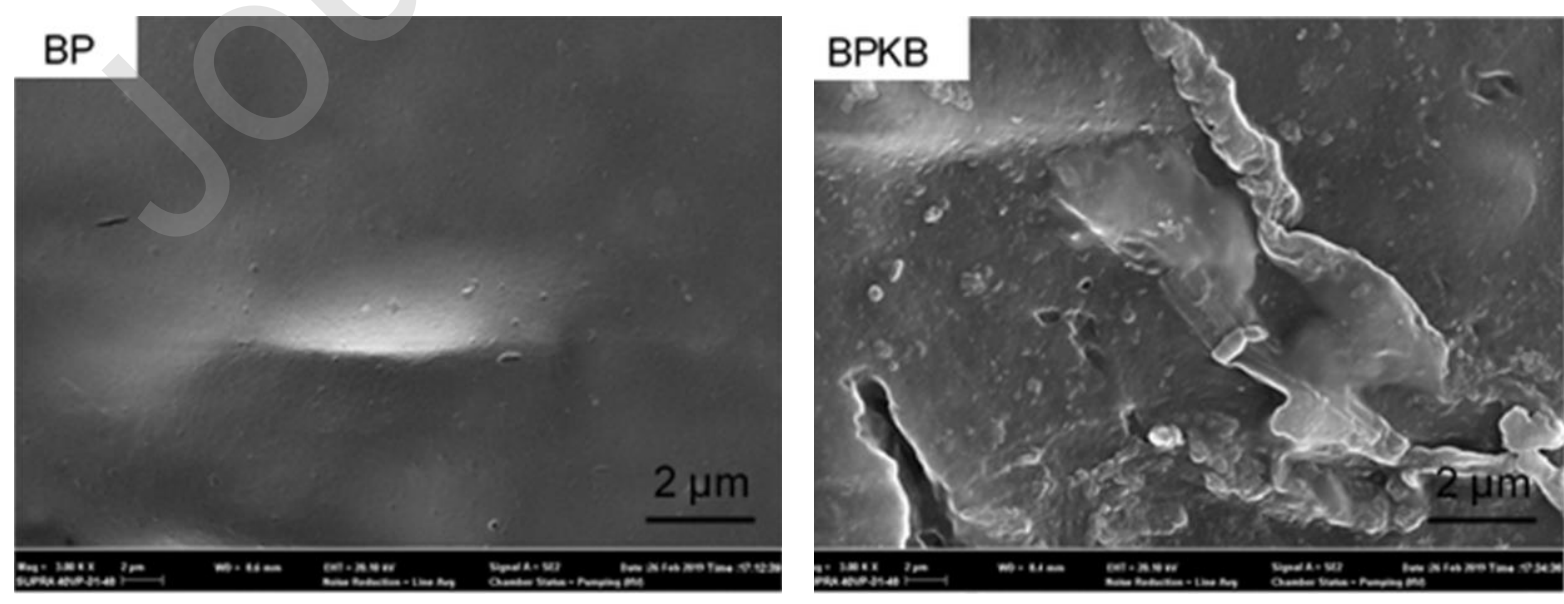
Figure 5: Scanning Electron Microscopy images of bioplastics. BP, Non-reinforced bioplastics; BPKB, Reinforced bioplastics with crude kaolin; BPMKB, Reinforced bioplastics with metakaolin

\subsection{Interaction mechanism}

The decrease in the solubility, diffusion and permeability of water of the thermally modified kaolin-reinforced bioplastics could be attributed to the improvement of their microstructure. The good dispersion of the fine particles of metakaolin platelets in BPMKB allowed to strongly reduce the starch macromolecule pore size inducing a more compact arrangement of those macromolecular chains. Through the electron doublets available on the oxygen atoms, the basal surfaces interacted with the functional groups of the starch macromolecules according to the mechanism proposed in Figure 6. Due to its amorphous character which increased its reactivity, metakaolin could strongly interact with starch macromolecules (Angellier, 2005; Wahyuningtiyas \& Suryanto, 2018). These interactions led to the creation of strong hydrogen bonds thus promoting the improvement of the microstructure of the final material (Monteiro et al., 2018).

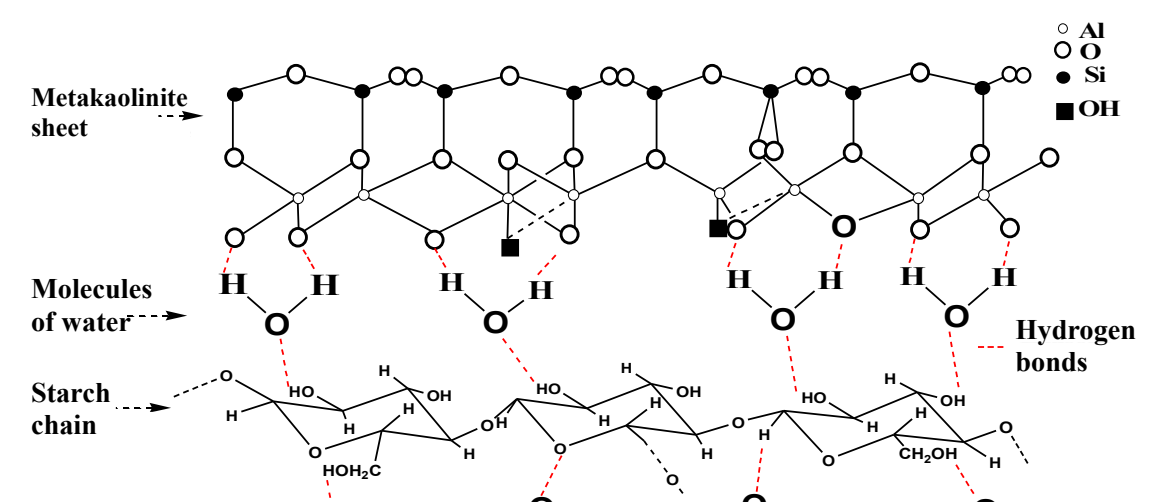


Figure 6: Schematic representation of the interactions between starch macromolecules and clay platelets: case of metakaolin.

\subsection{Biodegradability of bioplastics}

The biodegradability of the bioplastics produced was assessed by determining the mass loss of the samples as a function of the exposure time on the soil surface and the burial time in the ground (Figure 7). The obtained values of mass loss were almost zero during the first two weeks for all studied bioplastics and regardless of the environmental medium. It was the period of adaptation of microorganisms to their new environment before growing. Between two and three weeks, a rapid increase in weight loss was observed for all the bioplastics due
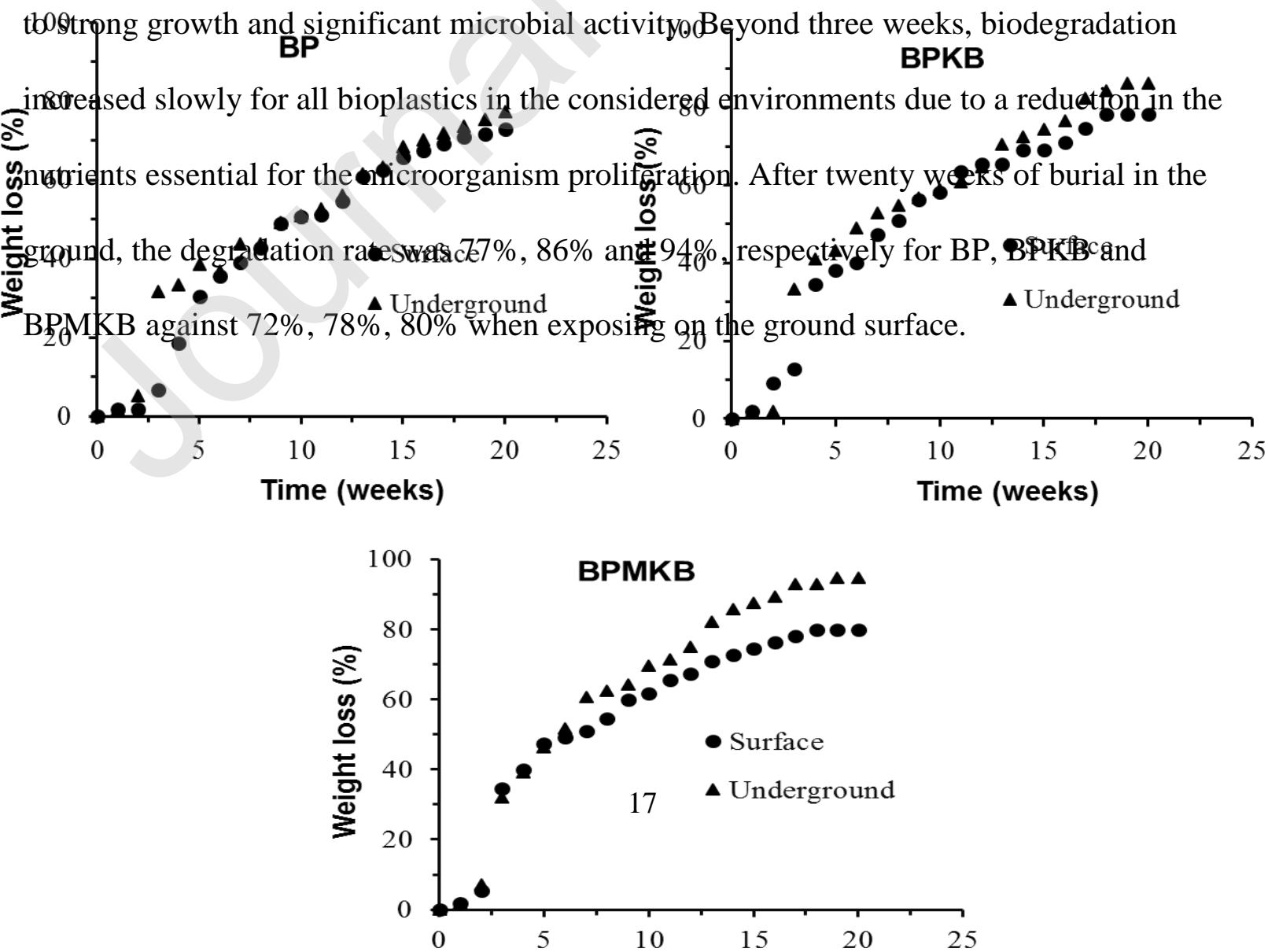
Figure 7: Degradation of elaborated bioplastics exposed to different environment over time. The significant degradation observed for all bioplastics when they were buried in the ground could be explained by a larger contact surface with microorganisms. In addition, the
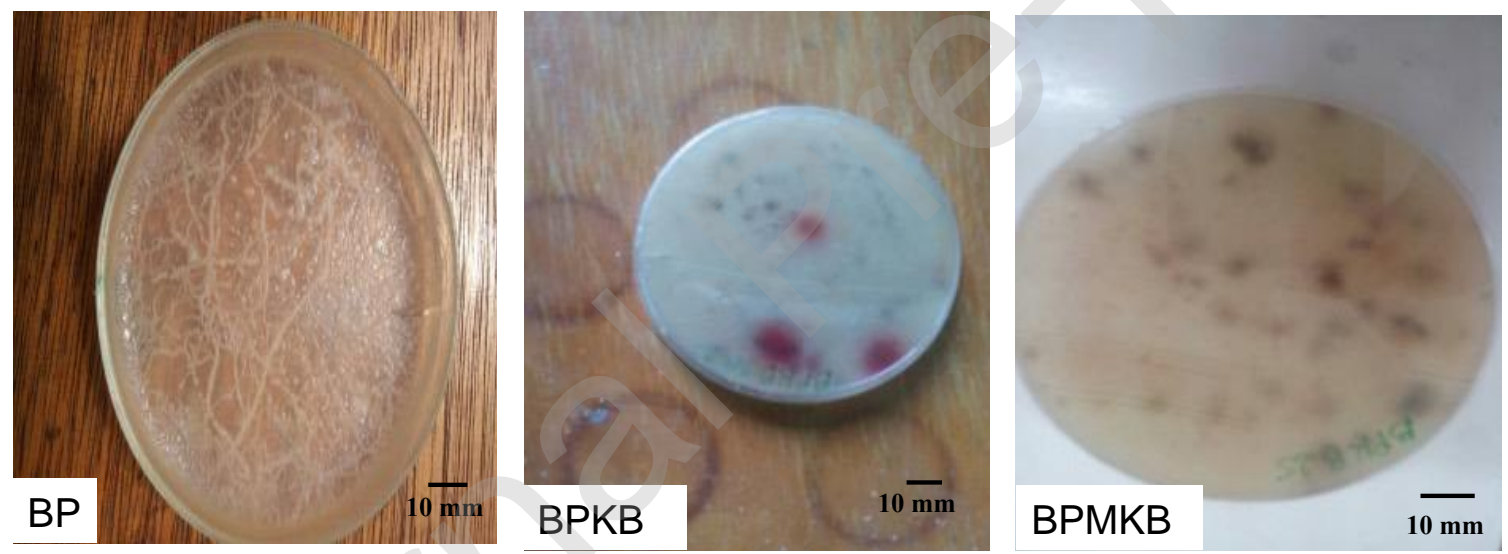

Figure 8: Images of bioplastics colonised by microorganisms. 
Observing the petri dishes containing BP revealed the presence of branched white filaments oriented in all directions. Whereas those containing BPKB and BPMKB showed the presence of numerous colored spots. The number of these spots was higher in the case of BPMKB. The presence of branched filaments in BP revealed the development of fungi. The growth of fungi generally resulted in an apical extension. The apical compartment had a very thin cell wall at the end which enabled it to extend in length by means of internal cytoplasmic turgor pressure. On the other hand, the presence of colored spots in BPKB and BPMKB reflected the proliferation of bacteria. This bacterial growth was induced by an increase in the number of cells resulting from cell division. In general, bacterial growth, qualified as exponential due to the duplication process through binary fission, was faster than that of fungi (Madigan \& Martinko, 2007 ; Edhirej et al., 2016). For the BPMKB plastic film, a significant presence of colored spots could explain the more pronounced degradation resulting in higher mass loss observed in Figure 7.

Authors contributions

-Namory Méité : Performed wet lab analysis using optimized protocols and editing of the manuscript.

- Léon Koffi Konan : Guided and monitored the experiment in reviewing and editing of the manuscript.

- Monique Tohoué Tognonvi : Helped in writing and clays data analysis

- Bi Irié Hervé Gouré Doubi : Helped in writing and drafting of the manuscript

- Moussa Gomina : Helped in writing and drafting of the manuscript.

- Samuel Oyetola : Helped in reviewing and editing of the manuscript. 


\section{Conclusion}

The thermal treatment of kaolin at $700{ }^{\circ} \mathrm{C}$ for 1 hour enabled to obtain metakaolin with an amorphous and dehydroxylated structure. Bioplastics made from cassava starch reinforced with $5 \%$ by mass of metakaolin presented lower water sensitivity and more compact microstructure than non-reinforced BP and those reinforced with crude kaolin. Moreover, the biodegradability of these bioplastics was slightly improved due to bacterial activity regardless of the exposure environment. The improvement in the hydric properties and the biodegradable nature indicated that heat treatment could help to open up more prospects for the use of kaolinitic clays in the dissemination of starch-based bioplastics. The permeability of cassava starch-based bioplastics reinforced with calcined clay platelets to certain gases such as dioxygen $\left(\mathrm{O}_{2}\right)$, ethylene $\left(\mathrm{C}_{2} \mathrm{H}_{4}\right)$ and carbon dioxide $\left(\mathrm{CO}_{2}\right)$ will be investigated in future works.

\section{References}

Angellier, H. (2005). Nanocristaux d'amidon de maïs cireux pour applications composites, University of Joseph-Fourier - Grenoble I, France. Retrieved from https://tel.archives373 ouvertes.fr/tel-00010699

Amon, L. N., Konan, K. L., Goure-Doubi, H., Andji J. Y. Y., Kalpy-Coulibaly, J., \& Oyetola, S. (2017). Physico-chemical and structural properties of clay-based ceramic filters from Côte d'Ivoire. J. Soc. Ouest-Afr. Chim., 044, 70-77

Arvis, I., \& Jarvis, K. E. (1992). Inductively coupled plasma-atomic emission spectrometry in exploration geochemistry. J. Geochem. Expl., 44, 139-200.

Belibi, P. C. (2013). Elaboration et caractérisation des biofilms à base d'amidon de manioc renforcés par des charges minérales bi et tri-dimensionnelles, University of Haute Alsace - Mulhouse, France. Retrieved from https://tel.archives-ouvertes.fr/tel-01202602 Belyamani, I. (2012). Développement d'un matériau thermoplastique biodégradable et hydrosoluble à base d'une protéine du lait, University of Jean Monnet, St Etienne, France. Retrieved from https://tel.archives-ouvertes.fr/tel-00702749 
Chivrac, F., Angellier-Coussy, H., Guillard, V., Pollet, E., \& Avérous, L. (2010). How does water diffuse in starch/montmorillonite nano-biocomposite materials? Carbohydrate Polymers, 82(1), 128-135. https://doi.org/10.1016/j.carbpol.2010.04.036

Cruz-Tirado, J.P., Ferreira, R. S. B., Lizárraga, E., Tapia-Blácido, D. R., Silva, N.C.C., Angelats-Silva, L., \& Siche, R. (2020). Bioactive Andean sweet potato starch-based foam incorporated with oregano or thyme essential oil. Food Packaging and Shelf Life, 23, 100457. https://doi.org/10.1016/j.fpsl.2019.100457

Edhirej, A., Sapuan, S. M., Jawaid, M. Q., \& Zahari, N. I. (2016). Preparation and characterization of cassava starch/peel composite film. Polymer Composites, 39(5), 1704-1715. https://doi 10.1002/pc.24121

Freitas, R., Paula, R., Feitosa, J. P., Rocha, S., \& Sierakowski, M.-R. (2004). Amylose contents, rheological properties and gelatinization kinetics of yam (Dioscorea alata) and cassava (Manihot utilissima) starches. Carbohydrate Polymers, 55(1), 3-8. https://doi.org/10.1016/S0144-8617(03)00142-5

Greenspan, L. (1977). Humidity fixed points of binary saturated aqueous solutions. Journal of research of the National Bureau of Standards- A Physics and Chemistry, 81A(1), 89-96. https://doi.org/10.6028/jres.081A.011

Harding, K. G., Gounden, T., \& Pretorius, S. (2017). "Biodegradable” plastics: A myth of marketing? Procedia manufacturing, 7, 106-110. https://doi.org/10.1016/j.promfg.2016.12.027

Islam, H. B. M. Z., Susan, M. A. B. H., \& Imran, A. B. (2020). Effects of plasticizers and clays on the physical, chemical, mechanical, thermal, and morphological properties of potato starch-based nanocomposite films. ACS Omega, 5(28), 17543-17552. https://dx.doi.org/10.1021/acsomega.0c02012

Kaewtatip, K., \& Tanrattanakul, V. (2012). Structure and properties of pregelatinized cassava starch/kaolin composites. Materials and Design, 37, 423-428.

https://doi:10.1016/j.matdes.2011.12.039

Konan, K. L., Soro, J., Andji, J. Y.Y., Kra G., \& Oyetola, S. (2010). Etude comparative de la déshydroxylation/amorphisation dans deux kaolins de cristallinité différente. J. Soc. Ouest-Afr. Chim, 30, 29-39.

Konan, K. L., Sei, J., Soro, N. S., Oyetola, S., Gaillard, J.-M., Kra, G., \& Bonnet, J-P. (2006). Caracterization of Azaguie-Blida site clay materials (Anyama, Côte d'Ivoire) and 
determination of ceramic products mechanical properties. J. Soc. Ouest-Afr. Chim, 21, $35-43$.

Madigan, M., \& Martinko, J. (2007). Brock, biologie des micro-organismes. Pearson France, Ed. Montreuil.

Mbey, J. A. (2013). Films composites amidon de manioc-kaolinite : influence de la dispersion de l'argile et des interactions argile-amidon sur les propriétés des films, University of Lorraine, France. Retrieved from https://hal.univ-lorraine.fr/tel-01749332

Meite, N., Konan, K. L., Bamba, D., Goure-Doubi B. I. H., \& Oyetola S. (2018). Structural and thermomechanical study of plastic films made from cassava-starch reinforced with kaolin and metakaolin. Materials Sciences and Applications, 9(1), 41-54. https://doi.org/10.4236/msa.2018.91003

Monteiro, M. K. S., Oliveira, V. R. L., Santos, F. K. G., Barros Neto, E. L., Leite, R. H. L., Aroucha, E. M. M., et al. (2018). Incorporation of bentonite clay in cassava starch films for the reduction of water vapor permeability. Food Research International, 105, 637644. doi: 10.1016/j.foodres.2017.11.030

Sei, J., Jumas, J. C., Olivier-Fourcade, J., Quiquampoix, H., \& Staunton, S. (2002). Role of iron oxid the phosphate adsorption properties of kaolinites from the Ivory Coast. Clays and Clay Minerals, 50(2), 217-222. https://doi.org/10.1346/000986002760832810

Sidibé, D., Sako, A., Ezoua, P., Kouame, C., Dally, L. I., \& Kati-Coulibaly, S. (2010). Comportement hydrothermique des amidons de 4 variétés de manioc (Manihot esculenta Crantz) cultivées en Côte d'Ivoire. International Journal of Biological and Chemical Sciences, 3(6), 1467-1479. https://doi.org/10.4314/ijbcs.v3i6.53543

Siracusa, V. (2019). Microbial degradation of synthetic biopolymers waste. Polymers, 11(6), 1066-1084, https:// doi:10.3390/polym11061066

Souza, A. C., Benze R., Ferrão, E. S., Ditchfield, C., Coelho, A. C. V., \& Tadini, C. C. (2012). Cassava starch biodegradable films: Influence of glycerol and clay nanoparticles content on tensile and barrier properties and glass transition temperature. LWT - Food Science and Technology, 46(1), 110-117. https://doi.org/10.1016/j.lwt.2011.10.018

Sperinck, S., Raiteri, P., Marks, N., \& Wright, K. (2011). Dehydroxylation of kaolinite to metakaolin-a molecular dynamics study. Journal of Materials Chemistry, 21, 18-25. https://doi.org/10.1039/C0JM01748E

Tyagi, V., \& Bhattacharya, B. (2019). Role of plasticizers in bioplastics. MOJ Food Process Technol., 7(4), 128-130. https://doi: 10.15406/mojfpt.2019.07.00231 
Wahyuningtiyas, N. E., \& Suryanto, H. (2018). Properties of cassava starch based bioplastic reinforced by nanoclay. Journal of Mechanical Engineering Science and Technology, 2(1), 20-26. https://dx.doi.org/10.17977/um016v2i12018p020

Yéboué, K. H., Amoikon, K. E., Kouamé, K. G., \& Kati-Coulibaly, S. (2017). Valeur nutritive et propriétés organoleptiques de l'attiéké, de l'attoukpou et du placali, trois mets à base de manioc, couramment consommés en Côte d'Ivoire. Journal of Applied Biosciences, 113(1),11184-11191. https:// doi: 10.4314/jab.v113i1.7 
Authors

\section{Dr. Namory Méité}

Doctor (Chemistry)

Master (Educational Sciences)

Email address : namorymeite2986@gmail.com

\section{Dr. Léon Koffi KONAN}

\section{Professor}

Research Professor at Félix Houphouët-Boigny University

Vice-Dean in charge of pedagogy at UFR SSMT/ Félix Houphouët-Boigny University

Email address : leonkonan2000@yahoo.fr

\section{Dr. Monique Tohoué Tognonvi}

Lecturer

Research Professor at Peleforo Gon Coulibaly University

Email address : monique.tognonvi@upgc.edu.ci

\section{Dr. Bi Irié Hervé Goure Doubi}

Lecturer

Research Professor at Peleforo Gon Coulibaly University

Email address : goure_herve2610@yahoo.fr

\section{Dr. Moussa Gomina}

Researcher

CNRS, ENSI-CAEN, France

Email address : moussa.gomina@ensicaen.fr

\section{Pr. Samuel Oyetola}

Full Professor

Research Professor at Félix Houphouët-Boigny University

Director of the inorganic materials chemistry laboratory/UFR-SSMT

Email address : oyetolasamuel@yahoo.fr 
